\title{
Resident's acceptance of internal courtyard buildings
}

\author{
Adi Ainurzaman Jamaludin ${ }^{1, a}$, Hazreena Hussein ${ }^{2}$ and Kauthar Md. Tahir ${ }^{1}$ \\ ${ }^{1}$ Institute of Biological Sciences, Faculty of Science, University of Malaya, 50603 Kuala Lumpur, Malaysia \\ ${ }^{2}$ Department of Architecture, Faculty of Built Environment, University of Malaya, 50603 Kuala Lumpur, Malaysia
}

\begin{abstract}
The internal courtyard of the residential building creates a micro-environment that provides a comfortable indoor environment. The acceptance of the courtyard by residents is disreputable even though its benefits have been scientifically proven. A survey using a set of questionnaire was carried out at two residential colleges to gauge the acceptance level of residents towards an existing internal courtyard. Results show that the majority of respondents of both residential colleges have given positive feedbacks, which include the perception on building and landscape designs in general, the quality of the landscape setting at the internal courtyard, the frequency of the time spent at the internal courtyard in a day, and the influence of the landscape setting at the internal courtyard on the quality of life. These feedbacks are not influenced by the gender aspect holistically. Indirectly, it indicates that the internal courtyard is positively relevant to be applied to the building design, particularly low-rise residential buildings.
\end{abstract}

\section{Introduction}

Courtyard in residential buildings is commonly applied for the purpose of promoting comfortable indoor environments by offering natural ventilation and daylighting into buildings. In the Middle East, courtyards provide the much-needed security and privacy for residents while reducing the infiltration of hot and dusty winds into the rooms with tall walls that build around the courtyard [1]. Courtyard creates a micro-environment that provides very pleasant living spaces with the presence of healing elements such as trees, flowers, shrubs and a pool of water [1-2].

The influence of a courtyard on the thermal condition has a strong reliance on the envelope opening and exhibits a better energy performance in hot-dry and hothumid climates [3-5]. According to Almhafdy et al. [2], the development of a courtyard has moved forward into the era of sustainability and green architecture, where the courtyard configurations can be classified into four. There are:

- Cluster courtyard

a. Multiple : the design of the building creates four fully-enclosed courtyards.

b. Spinal : More than one courtyard is attached to the building's central circulation route.

- Open courtyard : Group of buildings frame open spaces into the courtyards.

- Closed courtyard : The courtyard is fully enclosed.

- Complex/Interlinked courtyard : Courtyards are located on different floors and serving different purposes.

Generally, the U-shape of a courtyard with an aspect ratio of $1: 2$, which is considered as a rectangle has a better

\footnotetext{
${ }^{a}$ Corresponding author: adiainurzaman@um.edu.my
}

performance in terms of the thermal comfort as compared to the U-shape of a courtyard with an aspect ratio of $1: 1$, which is considered as a square [6].

The successful attribute of a courtyard in building designs is not limited to providing comfortable indoor environments and efficient use of electricity. It should be extended to the residents' acceptance to understand the mutual interactive process between the building and the user's needs [7]. Thus, the wastage of maintenance and operating costs can be evaded as the residents' actual needs are determined proximately. Furthermore, having a courtyard would improve the quality of the facilities, morale and work performance of the residents [8]. According to Ilesanmi [9], the residents' perception of a proper residential environment cannot be ignored at the policy, planning, design and implementation levels where satisfaction with the physical environment of the residence is the most powerful predictor of residential satisfaction. Thus, the notable design features can be repeated in future development, and any redundant or unnecessary building features will be eliminated. In order to ensure that the building continues to deliver appropriate levels of satisfaction to the end-user, the critical evaluation in terms of the acceptance and perception should not only occur in a facility once it is constructed and occupied, but it should also be carried out throughout the entire building delivery cycle [10-11]. It is necessary to focus on the most relevant issues rather than to attempt to analyse everything and risk an overload of data [12].

We have a shortage of residents' acceptance studies on the internal courtyard at residential buildings, particularly in tropical climate regions. 
Most of the reported studies are experimental studies that focus on the advantages and disadvantages of the internal courtyard in terms of natural ventilation and daylighting, either through the field measurement or simulation $[3,4$, $6,13,14]$. Therefore, the aim of this research is to evaluate the residents' acceptance level of two residential colleges with an internal courtyard arrangement, with the purpose of justifying the relevance of the internal courtyard in the building design, particularly low-rise residential buildings. Further statistical analysis was done to measure the acceptance level based on the gender perspective.

\section{Research methods}

A survey using a set of questionnaire on residents' acceptance was conducted based on a study by Jamaludin et. al [15]. There are only four questions covering the perception on building and landscape designs in general, the quality of the landscape setting at the internal courtyard, the frequency of the residents spending time at the internal courtyard in a day, and the influence of the landscape setting at the internal courtyard on the quality of life. The questionnaire uses a Likert Scale format where each number responds to a specific scale as listed in Table 1.

Table 1. Likert Scale used in satisfaction survey.

\begin{tabular}{|c|c|c|c|c|}
\hline \multicolumn{5}{|c|}{ Likert Scale } \\
\hline $\mathbf{- 2}$ & $\mathbf{- 1}$ & $\mathbf{0}$ & $\mathbf{+ 1}$ & $\mathbf{+ 2}$ \\
\hline $\begin{array}{c}\text { Strongly } \\
\text { disagree }\end{array}$ & Disagree & Undecided & Agree & $\begin{array}{c}\text { Strongly } \\
\text { Agree }\end{array}$ \\
\hline $\begin{array}{c}\text { Very } \\
\text { poor }\end{array}$ & Poor & Fair & Good & Very good \\
\hline Never & Rarely & Sometimes & Frequently & $\begin{array}{c}\text { Every } \\
\text { time }\end{array}$ \\
\hline Not at all & Slightly & Moderate & Very & Extremely \\
\hline
\end{tabular}

The questionnaires were distributed to all residents with the minimum feedbacks relying on $95 \%$ of confident level and $\pm 5 \%$ margin of error from the overall population. The calculation of the sample size is based on the formula [16]:

$$
n=N / 1+N(e)^{2}
$$

Where, $\mathrm{n}$ is the sample size, $\mathrm{N}$ is the population size and $\mathrm{e}$ is the level of precision. A statistical software package has been used to analyse all the questionnaires collected. Further analysis was done to see the acceptance level based on the gender perspective.

\section{Building description}

\subsection{RC-A}

RC-A is the $5^{\text {th }}$ Residential College known as Dayasari Residential College. It is located in the University of Malaya, Kuala Lumpur.
Built in 1966, this residential college was able to accommodate 847 residents at any single time. It consists of five residential blocks with three-floor levels each, excluding a ground floor. The site plan and typical floor plan of the RC-A are presented in Figures 1 and 2.

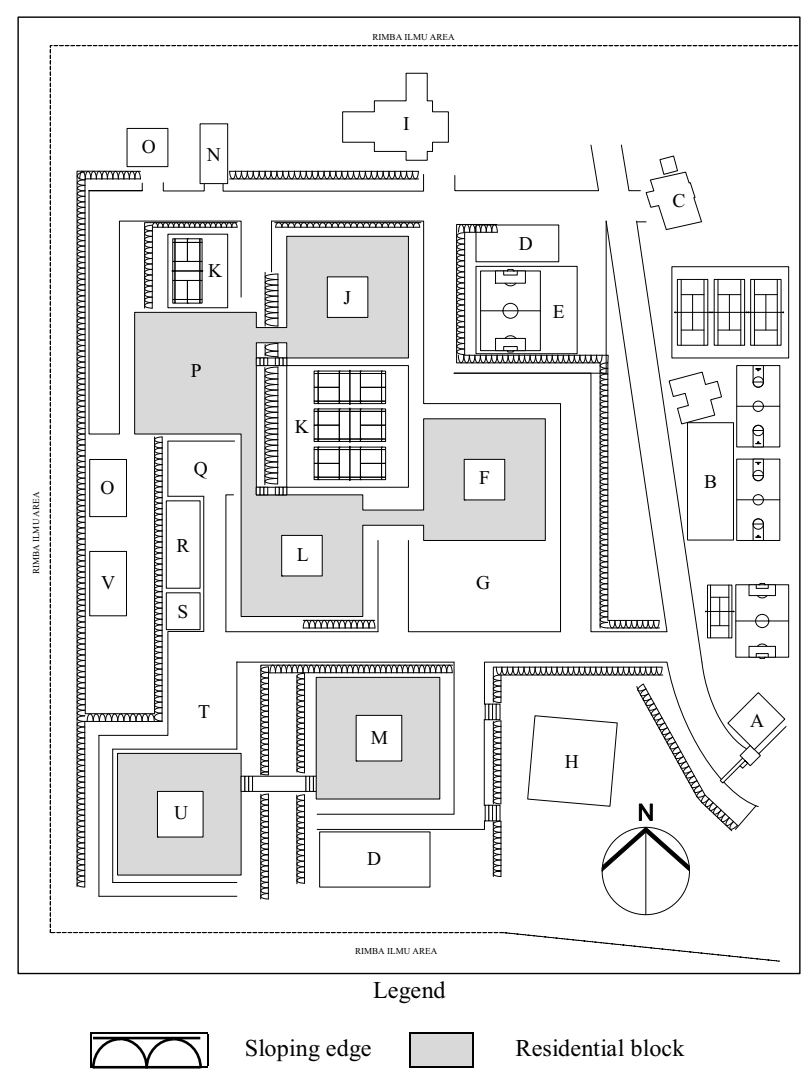

A - Guard post/Main entrance, B - Court/Sport centre/Multipurpose open area, C Cafeteria, D - Sewage tank, E - Field/ Multipurpose open area, F- Residential block (Block B - Boungainvilla/ Female), G - Garden/ Green area, H - Prayer Hall/Musollah, I - Principal unit, J - Residential block (Block A - Azalea/Female), K - Court/ Multipurpose open area, L - Residential block (Block C - Camellia/ Female), M - Residential block (Block D - Dahlia/ Male), N - Self car wash, O Store, P - Administrative block/Office, Lobby, Students activity centre, Dining hall, Kitchen, Q - Parking lots, R - Self-laundry room \& Covered parking lots, S Pump house, T - Parking lots/ Multipurpose open area, U - Residential block (Block E - Episcia/Male), V - Staff residential units

Figure 1. Site plan of RC-A.

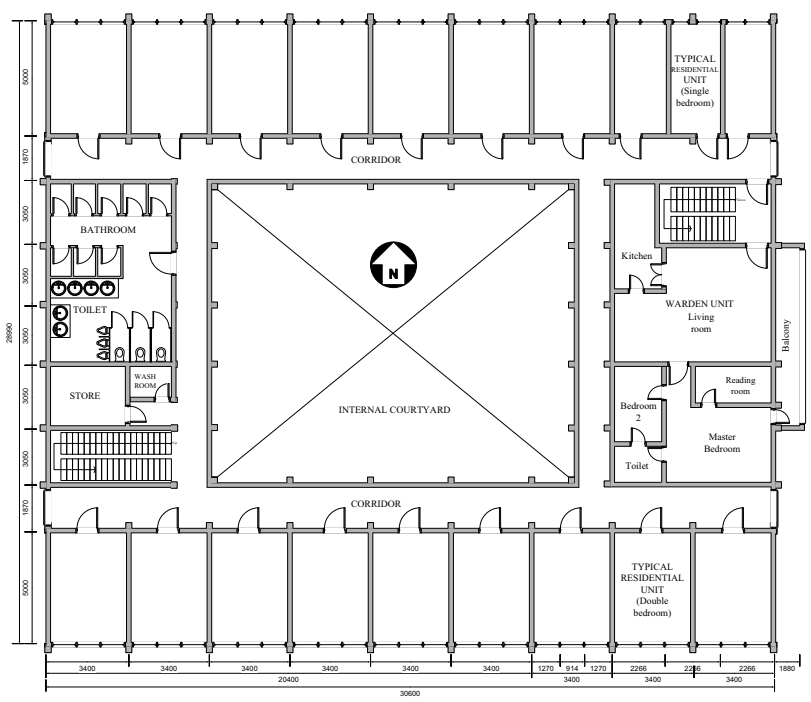

Figure 2. Typical floor plan of RC-A. 
The residential building is designed with an internal courtyard arrangement and rectangle shape of the building's floor plate. The total floor area is $18,212.51 \mathrm{~m}^{2}$, while the room's floor area and volume are $16.35 \mathrm{~m}^{2}$ and $45.78 \mathrm{~m}^{3}$, as the typical room dimension is $4.74 \mathrm{~m}$ (1) $\mathrm{x}$ $3.45 \mathrm{~m}(\mathrm{w}) \times 2.80 \mathrm{~m}(\mathrm{~h})$. Most of the rooms, especially the ones at the middle of the floor are directly facing the internal courtyard. This promotes natural ventilation and daylighting inside the rooms through transoms on top of the entrance door and wall. The area of the internal courtyard is $239.88 \mathrm{~m}^{2}$, planted with grass and shrubs. There is a small hut, known as gazebo that functions as a social or engagement space for the residents.

With regard to the enclosure and façade design, there are centre pivots and awning window design with tinted glasses in each room. The different types of windows help to channel outside air/wind from a different angle, while giving residents full control towards daylighting besides the large horizontal overhangs along the wall with windows. The characteristics of the RC-A are visualised through the standard regular photographs presented in Figure 3.

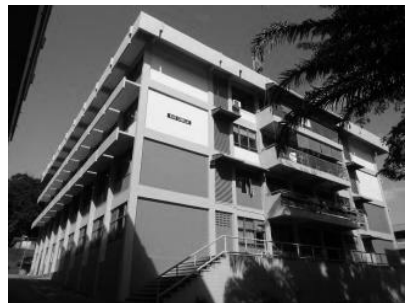

(a)

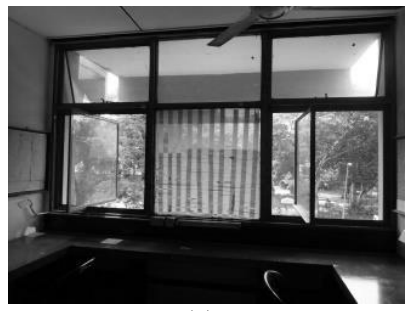

(c)

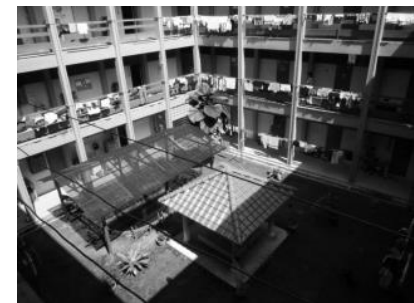

(b)

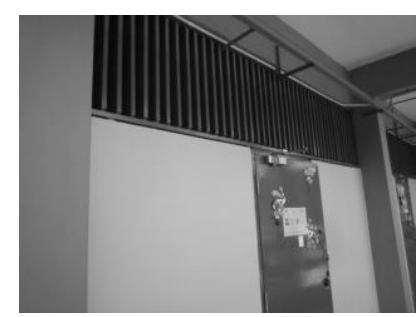

(d) (a). Built-form configuration, enclosure and facade design Large horizontal overhangs along the wall with windows, (b). Internal courtyard in the middle of residential building, (c). Centre pivots \& awning window design with tinted glass, (d). Transom/fixed opening over the doorway of residential unit.

Figure 3. The characteristics of RC-A.

\subsection{RC-B}

$\mathrm{RC}-\mathrm{B}$ is the $11^{\text {th }}$ Residential College known as the Ungku Aziz Residential College. Located at the University of Malaya, it was established in 1998. This residential building provides comfortable and spacious rooms with 897 residents. The RC-B only consists of four residential blocks with three floor levels each, excluding a ground floor. The site plan and typical floor plan of the RC-B are presented in Figures 4 and 5. Similar to the RC-A, RC-B was designed with an internal courtyard arrangement in an L-shape of the building's floor plate. The total floor area is $34,305.32 \mathrm{~m}^{2}$.

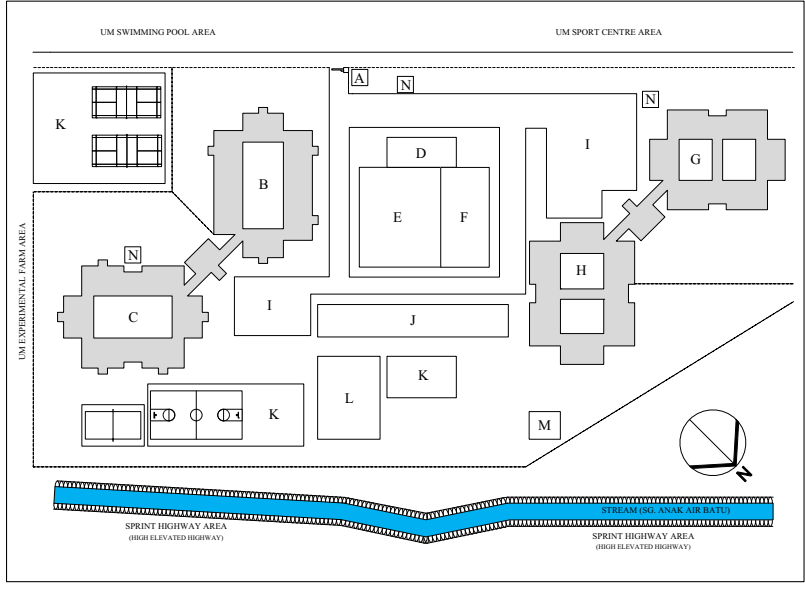

Legend

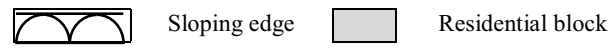

A - Guard post/Main entrance, B - Residential block (Block A - Awana/Female), C - Residential block (Block B - Bayu/Male), D - Administrative block/Office, E Hall/Student activity centre, F - Student activity centre, G - Residential block (Block C - Flora/Female), H - Residential block (Block D - Impiana/ Male), I Parking lots/Multipurpose open area, J - Cafeteria/Food court, K - Court/Sport area/ Multipurpose open area, L - Covered parking lots, M - Store, N - Gazebo.

Figure 4. Site plan of RC-B.

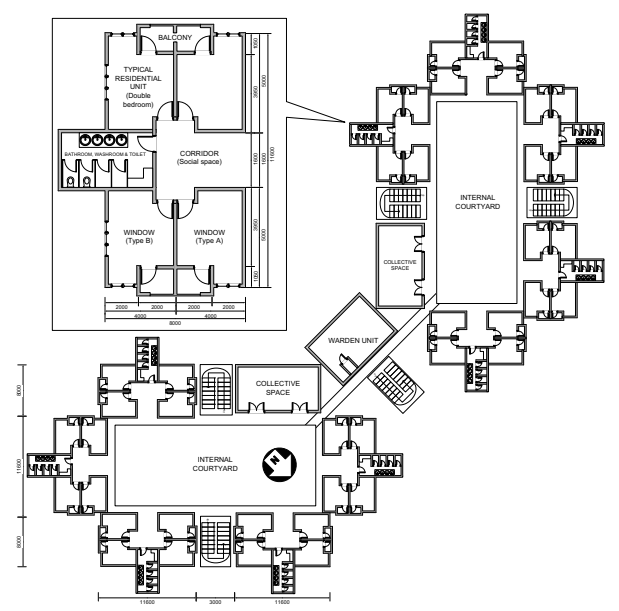

Block A and Block B

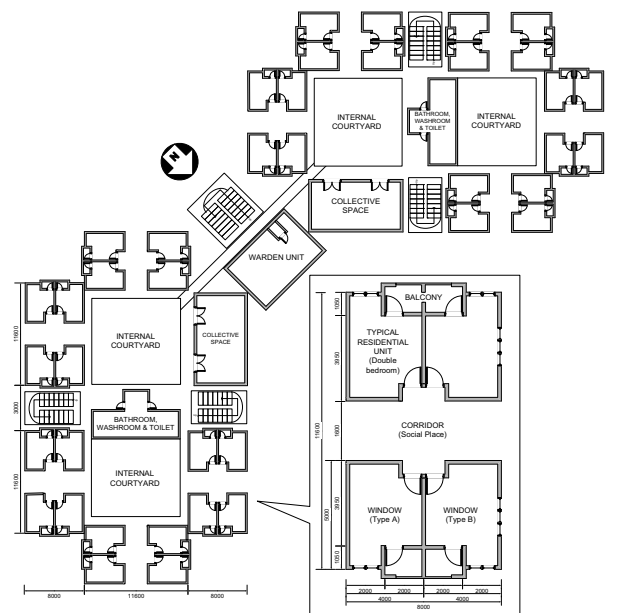

Block C and Block D

Figure 5. Typical floor plan of RC-B. 
The room's floor area and volume are $20.00 \mathrm{~m}^{2}$ and $57.40 \mathrm{~m}^{3}$, respectively, whereas the room dimension is $5.0 \mathrm{~m}(\mathrm{l}) \times 4.0 \mathrm{~m}(\mathrm{w}) \times 2.87 \mathrm{~m}(\mathrm{~h})$. There are four rooms with the entrance facing each other and forming a cubicle. There are five cubicles with one collective space in each floor. Each cubicle is connected through an open corridor that faces the internal courtyard. The total area of the internal courtyard is $303.92 \mathrm{~m}^{2}$ for blocks A and B, and $269.12 \mathrm{~m}^{2}$ for blocks $\mathrm{C}$ and $\mathrm{D}$. The internal courtyard area is planted with grass and shrubs.

In providing a control to the residents over the natural ventilation and daylighting, each room was designed with a balcony and two different types of windows. They are casement and turn windows with tinted glass. The characteristics of the RC-B are visualised through the standard regular photographs that are presented in Figure 6.

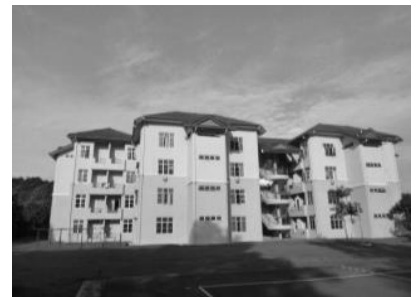

(a)

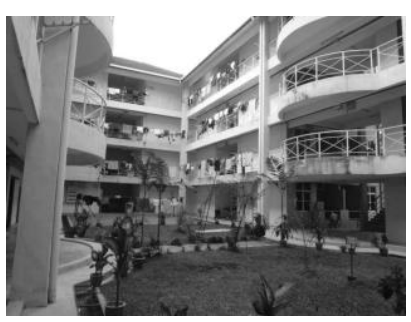

(b)

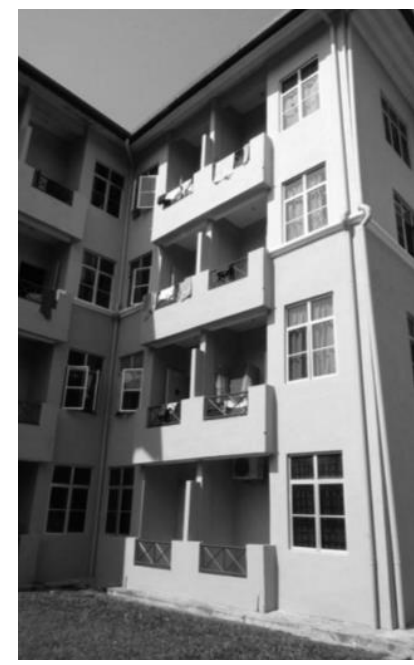

(c) (a). Built-form configuration, enclosure and facade design Large horizontal overhangs along the wall with windows, (b). Internal courtyard in the middle of residential building, (c). Casement and turn window design with tinted glass and large balcony in each residential unit faces to outside areas.

Figure 6. The characteristics of RC-A.

\section{Results and discussion}

A total of 266 responses retrieved were fully supplied by the respondents at the RC-A of which $39.6 \%$ are male and $60.4 \%$ are female residents. The number of respondents exceeded the minimum number of feedbacks required for a reliable $95 \%$ confidence level and $\pm 5 \%$ margin of error from the overall population. The result of the residents' acceptance survey at the RC-A is presented in Table 2.

Only 181 responses were fully filled in by the respondents at the $\mathrm{RC}-\mathrm{B}$, accounting for $40.9 \%$ male and $59.1 \%$ female residents. This number only exceeds the minimum number of respondents as relying on $85 \%$ confidence level and $\pm 5 \%$ margin of error from the overall population. The result of the residents' acceptance survey at the RC-B is presented in Table 3.
Table 2. The result of the residents' acceptance survey at RC-A

\begin{tabular}{|l|c|c|c|c|c|}
\hline \multirow{2}{*}{ Question } & \multicolumn{5}{|c|}{$\begin{array}{c}\text { Likert scale / Residents' } \\
\text { responses (\%) }\end{array}$} \\
\cline { 2 - 6 } & $\mathbf{- 2}$ & $\mathbf{- 1}$ & $\mathbf{0}$ & $\mathbf{+ 1}$ & $\mathbf{+ 2}$ \\
\hline $\begin{array}{l}\text { The residential building is } \\
\text { sensitively designed for the } \\
\text { landscape setting }\end{array}$ & 1.5 & 7.3 & 39.7 & 43.1 & 8.4 \\
\hline $\begin{array}{l}\text { The quality of landscape } \\
\text { setting at the internal } \\
\text { courtyard }\end{array}$ & 1.5 & 6.1 & 35.9 & 48.9 & 7.6 \\
\hline $\begin{array}{l}\text { The frequency of spending } \\
\text { time at the internal courtyard } \\
\text { in a day }\end{array}$ & 11.5 & 14.9 & 29.0 & 38.5 & 6.1 \\
\hline $\begin{array}{l}\text { The influence of landscape } \\
\text { setting at the internal } \\
\text { courtyard on the quality of } \\
\text { life }\end{array}$ & 3.1 & 7.3 & 37.4 & 43.1 & 9.2 \\
\hline
\end{tabular}

Table 3. The result of the residents' acceptance survey at RC-B.

\begin{tabular}{|l|c|c|c|c|c|}
\hline \multirow{2}{*}{ Question } & \multicolumn{5}{|c|}{$\begin{array}{c}\text { Likert scale / Residents' } \\
\text { responses (\%) }\end{array}$} \\
\cline { 2 - 6 } & $\mathbf{- 2}$ & $\mathbf{- 1}$ & $\mathbf{0}$ & $\mathbf{+ 1}$ & $\mathbf{+ 2}$ \\
\hline $\begin{array}{l}\text { The residential building is } \\
\text { sensitively designed for the } \\
\text { landscape setting }\end{array}$ & 8.3 & 13.3 & 44.2 & 27.6 & 6.6 \\
\hline $\begin{array}{l}\text { The quality of landscape } \\
\text { setting at the internal } \\
\text { courtyard }\end{array}$ & 3.3 & 16.0 & 44.2 & 32.6 & 3.9 \\
\hline $\begin{array}{l}\text { The frequency of spending } \\
\text { time at the internal courtyard } \\
\text { in a day }\end{array}$ & 9.9 & 21.5 & 45.3 & 16.6 & 6.6 \\
\hline $\begin{array}{l}\text { The influence of landscape } \\
\text { setting at the internal } \\
\text { courtyard on the quality of } \\
\text { life }\end{array}$ & 7.7 & 12.7 & 44.2 & 24.3 & 11.0 \\
\hline
\end{tabular}

According to the percentage of figures in Table 2, the majority of respondents at the RC-A, who represented $43.1 \%$ of the respondents 'agreed' that the residential building, which was designed with an internal courtyard is sensitively designed for the landscape setting, whilst $48.9 \%$ voted 'good' on the quality of the landscape setting at the internal courtyard. Therefore, $43.1 \%$ who represented the majority agreed that the landscape setting at the internal courtyard had "very" much influenced their quality of life. This was despite the fact that only $38.5 \%$ of the respondents who represented the majority were 'frequently' spending time at the internal courtyard in a day.

By referring to Table 3, different results were obtained on the residents' acceptance survey at the RC-B. The majority of residents voted one rate lower for all four questions as compared to the responses given by the majority of residents at the RC-A. There was no decision made on the sensitivity of the building design with the landscape setting when $44.2 \%$ voted for 'undecided'. This happened when they claimed that the quality of the landscape setting at the internal courtyard is 'moderate'. Thus, $45.3 \%$ of respondents who represented the majority only ticked 'sometimes', meaning that they only spent time the internal courtyard occasionally in a day. Meanwhile, $44.2 \%$ of respondents claimed that the landscape setting is 'moderately' influential to their quality of life. 
The survey results of both residential colleges indicate that, the acceptance level of the residents is highly influenced by the arrangement and design of the internal courtyard. At the RC-A, the internal courtyard is facing most of the rooms directly, where the accessibility is not an issue to the residents especially for those who are living at the ground level. The gazebo as a social or engagement space for the residents, with the presence of shrubs and grass creates the internal courtyard that is fully functioning as a healing element, while improving the thermal comfort of the building's environment [2, 14].

A different situation can be seen at the RC-B, when all rooms are not directly facing the internal courtyard. There are only open corridors, which connect all cubicles, formed by four rooms facing each other. Thus, the internal courtyard is not fully utilised by the residents. This has been worsened by the modification of the internal courtyard by the residential college administration. The green ground of the internal courtyard in blocks $\mathrm{C}$ and $\mathrm{D}$ has been replaced with textured pavement and it has turned into a place to hang clothes for drying. In order to eliminate some of the weather elements from the space, a big polycarbonate roof was installed at the second floor of the building, as shown in Figure 7.

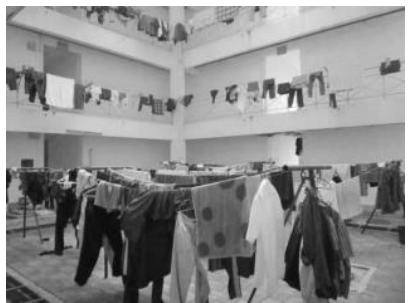

(a)

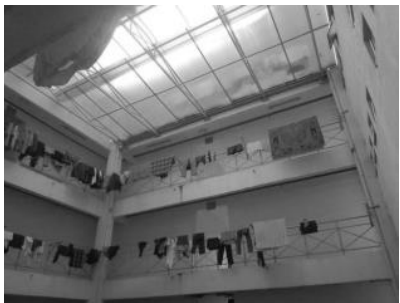

(b) (a). textured pavement, (b). a big polycarbonate roof.

Figure 7. Modification on internal courtyard in blocks C and D at RC-B.

In order to increase the residents' acceptance level, the modification of the internal courtyard should be done properly. The potential of the courtyard can be optimised, especially in the thermal performance if the particular design variants and configurations are known [14, 17]. According to Murgul [18], the accurate glazing of a courtyard is able to improve the quality of a courtyard space, especially on daylight and natural ventilation performance, increase the socialisation and interactions of dwellers, psychological relations with natural environment and ensure the protection from negative environmental impacts. Moreover, the commercial attractiveness and market value of a building. By making a comparison, open courtyard buildings that are relevant in all climates exhibit a better energy performance for the shorter buildings and as the building height increases, at the some point the enclosed atrium exhibits a better energy performance [13]. With regard to RC-B, which is designed with three-floor levels excluding a ground floor, the installation of the polycarbonate roof should highly be reconsidered with the building energy performance aspect.

Alternatively, the presence of the balcony in each room replaces the role of the internal courtyard as a social or engagement space to the residents at RC-B. The balcony improves view enjoyment by facing the wider outdoor landscape with diverse sceneries [19]. Thus, we need to provide the healing element efficiently with a better improvement of daylighting, thermal comfort and indoor air quality [2, 20,21]. Moreover, it offers residents a provision of privacy to socialise, as it has been identified as a significant space for social gatherings that also acts as buffer zones of a gentle transition between the public and private spaces [22].

Further analysis was done to see the acceptance level according to the gender perspective at both residential colleges, and this is as presented in Figure 8. There were no differences in the responses between both genders for all questions. Both female and male have the same perspective towards the internal courtyard in the residential college building. According to Othman et al. [23], gender has no significant difference on the landscape's aesthetic values and visiting performance in natural outdoor environment.

\section{Conclusion}

The internal courtyard is positively relevant to be applied to the building design, particularly low-rise residential buildings. In general, the design and arrangement of the internal courtyard influence the acceptance level of respondents. Meanwhile, both male and female gave the same responses that indirectly indicate that the acceptance towards the internal courtyard in a building is a not influenced by the gender aspect.

As a recommendation, it is necessary to have a greater number of respondents to obtain an accurate result of the survey to represent the overall population; it should exceed the minimum number of feedbacks with a $95 \%$ confident level and $\pm 5 \%$ margin of error. The scope of study should be expanded by including more questions and buildings as a case study for better understanding the best design of an internal courtyard at low-rise residential buildings.

\section{Acknowledgement}

The authors would like to thank Dayasari and Ungku Aziz Residential Colleges at the University of Malaya campus for their permission to carry out the survey. This analysis was financially supported by the Institut Pengurusan dan Pemantauan Penyelidikan (IPPP), the University of Malaya under BKP Grant (BK010-2015). 


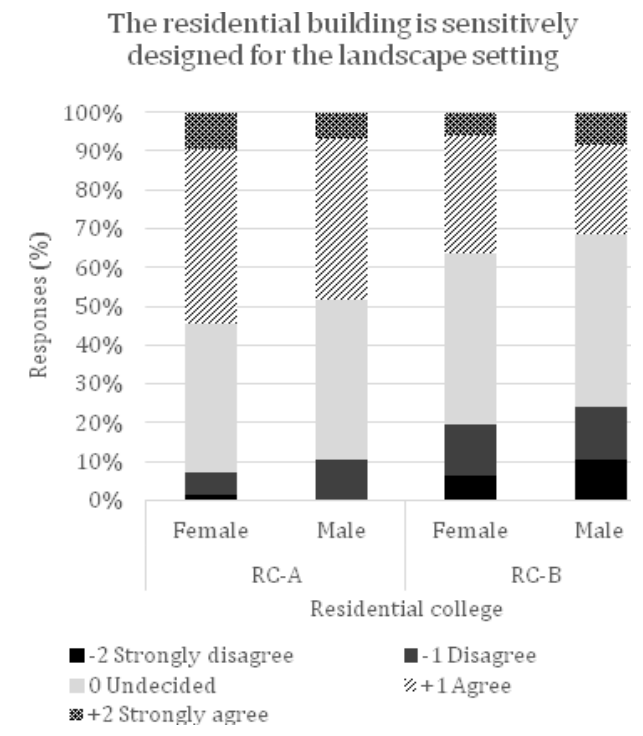

The quality of landscape setting at the internal courtyard

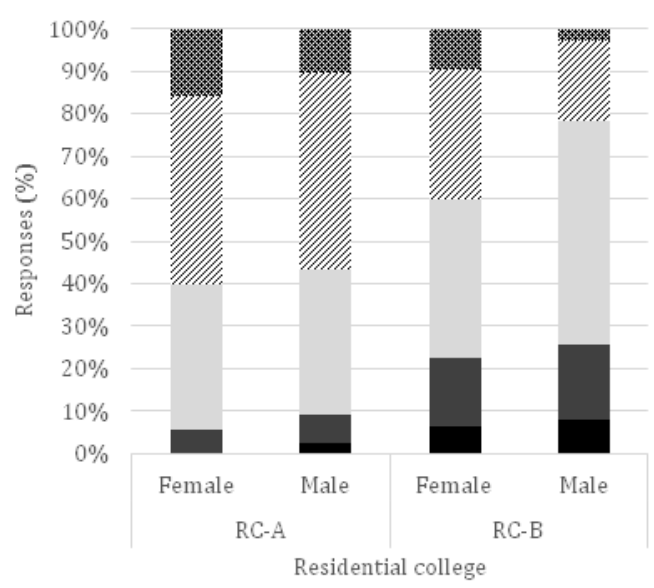

-2 Very poor -1 Poor 0 Fair " " +1 Good $*+2$ Very good

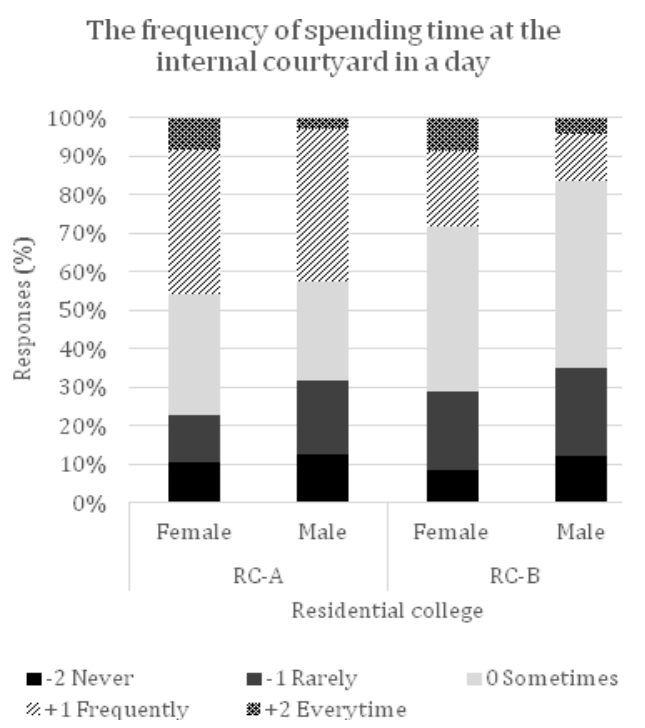

The influence of landscape setting at the internal courtyard on the quality of life

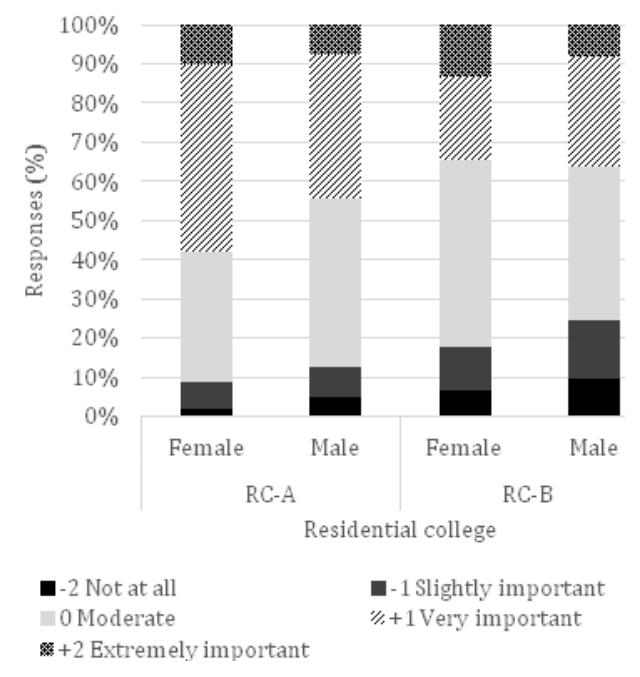

Figure 8. The result of residents' acceptance survey at RC-A and RC-B according to the gender.

\section{References}

1. H. Safarzadeh, M.N. Bahadori, Passive cooling effects of courtyards. Build. Environ. 40, 89-104 (2005)

2. A. Almhafdy, N. Ibrahim, S.S. Ahmad, J. Yahya, Analysis of courtyard functions and its design variants in the Malaysian hospital, Procedia Soc. Behav. Sci. 105, 171-182 (2013)

3. N. Sadafi, E. Salleh, L.C. Haw, Z. Jaafar, Evaluating thermal effects of internal courtyard in a tropical terrace house by computational simulation. Energ Buildings 43, 887-893 (2011)

4. M.A. Zakaria, T. Kubota, D.H.C. Toe, The effects of courtyards on indoor thermal conditions of Chinese shophouse in Malacca, Procedia Eng. 121, 468-476 (2015)

5. A. Aldawoud, Thermal performance of courtyard buildings, Energ. Buildings 40, 906-910 (2008)

6. A. Almhafdy, N. Ibrahim, S.S. Ahmad, J. Yahya, Thermal Performance Analysis of Courtyards in a Hot Humid Climate using Computational Fluid Dynamics CFD Method, Procedia Soc. Behav. Sci. 170, 474-483 (2015)

7. N. Khalil, H.N. Husin, A.H. Nawawi, A.E. Hashim, Post occupancy evaluation for performance evaluation of building facilities in higher education buildings, The proceeding of 9th International Conference SENVAR \& 2nd ISESEE 2008 (UiTM, Malaysia, 2008)

8. M.A. Hassanain, A. Sedky, Z.A. Adamu, A. Saif, A framework for quality evaluation of university housing facilities, J. Build. Apprais. 5, 213-221 (2010)

9. A.O. Ilesanmi, Post-occupancy evaluation and residents' satisfaction with public housing in Lagos, Nigeria, J. Build. Apprais. 6, 153-169 
10. W.F.E. Preiser, Post-occupancy evaluation: How to make buildings work better, Facilities 13, 19-28 (1995)

11. S. Turpin-Brooks, G. Viccars, The development of robust methods of post occupancy evaluation, Facilities 24, 177-196 (2006)

12. K. Hadjri, C. Crozier, Post-occupancy evaluation: Purpose, benefits and barriers, Facilities 27, 21-33 (2009)

13. A. Aldawoud, R. Clark, Comparative analysis of energy performance between courtyard and atrium in buildings, Energ. Buildings 40, 209-214 (2008)

14. A. Ghaffarianhoseini, U. Berardi, A. Ghaffarianhoseini, Thermal performance characteristics of unshaded courtyards in hot and humid climates, Build. Environ. 87, 154-168 (2015)

15. A.A. Jamaludin, N. Keumala, A.R.M. Ariffin, H. Hussein, Satisfaction and perception of resident towards bioclimatic design strategies: Residential college buildings, Indoor Built Environ. 23, 933-945 (2014)

16. T. Yamane, Statistic, an introductory analysis (Harper \& Row, New York, 1967)

17. A. Almhafdy, N. Ibrahim, S.S. Ahmad, J. Yahya, Courtyard design variants and microclimate performance, Procedia Soc. Behav. Sci. 101, 170180 (2013)

18. V. Murgul, Reconstruction of the Courtyard Spaces of the Historical Buildings of Saint-Petersburg with Creation of Atriums, Procedia Eng. 117, 808-818 (2015)

19. A.L.S. Chan, T.T. Chow, Investigation on energy performance and energy payback period of application of balcony for residential apartment in Hong Kong, Energ. Buildings 42, 2400-2405 (2010)

20. N. Lechner, Heating, cooling, lighting: Sustainable design methods for architects (John Wiley \& Sons, New Jersey, 2009)

21. M.F. Mohamed, S. King, M. Behnia, D. Prasad, The effects of balconies on the natural ventilation performance of cross-ventilated high-rise buildings, Journal of Green Building 9, 145-160 (2014)

22. J. Williams, Designing neighbourhoods for social interaction: The case of cohousing, J. Urban Des. 10, 195-227 (2005)

23. N. Othman, N. Mohamed, M.H. Ariffin, Landscape Aesthetic Values and Visiting Performance in Natural Outdoor Environment, Procedia Soc. Behav. Sci. 202, 330-339 (2015) 